\title{
画像の重站わせ手法と数量化理論を併用した 斜面崩壊発生箇所の分析
}

\author{
瀬戸島政博*・森大*・後藤恵之輔**
Analysis on the Occurrence of Slope Collapse by Jointly Using the Image Overlay Method and Quantification Method

\author{
Masahiro SETOJIMA*, Masaru MORI* and Keinosuke GOTO**
}

\begin{abstract}
Key words : リモートセンシング remote sensing, 画像の重ね合わせ手法 image overlay method, 数量化理 論 quantification method, ディジタル画像解析 digital image analysis, カラー空中写真画像 color photograph image, 斜面崩壊 slope collapse, 素因分析手法 analysis method on the factors
\end{abstract}

\begin{abstract}
In this study, we clarified the factors which highly relate to the occurrence of collapse by jointly applying the image overlay method and quantification method on the places where the collapse occurred at the surface layer in the past.

We also discussed the necessity to analyze the hazardous places where the collapse is anticipated occurring at the surface layer in the future, respectively for each pattern of occurrence.

We could obtain the following findings through this study :

(1) The collapses in the study area caused by the same reason (124 places) could be roughly classified into 6 patterns.

(2) By employing the analysis method with which image overlay method and quantification method were jointly used, we were able to surmise the relation between the location of past collapses and hazardous places where the collapse is anticipated in the future.
\end{abstract}

\section{1. 概 要}

斜面崩壊は, 特定の素因を有する場所で, 同一の誘因 によって発生する場合でも, 異なった崩壊の発生パター ン（例えば，傾斜を主因とする場合，集水条件を主因と

* 国際航業侏 Kokusai Kogyo Co., Ltd.

** 長崎大学工学部 Faculty of Engineering, Nagasaki University
する場合等）を有することがある。従来, 同一の素因情 報を用いて, 同一の崩壞発生パターンを想定し, 斜面崩 壊の素因を分析することが多かった。

崩壊の発生パターン別に区分を行った上で発生素因を 分析すれば，崩壊発生パターン別に卓越する素因や表層 部の崩壊に関与すると考えられる素因等が判明する可能 性がある。加えて, 表層部で発生する崩壊の発生パター ン区分に応じた解析を行うことができれば，発生素因に 基づく発生危険度予測の精度の向上が図れる。 
そこで, 本研究では, 1982年 7 月に発生した長崎大 水害に伴う表層部での崩壊箇所を対象に, 表層部の崩壊 の発生パターン区分を画像解析手法を主体に試みた。そ れにより, 崩壊発生パターン別に関与度合の高い素因情 報を明確にし，崩壊発生パターン別の類似箇所の推定を 試みた。

\section{2. これまでの研究上の課題}

最近, 斜面災害の発生危険度評価に関して, リモート センシングによる土地被覆・植生指標情報を加えた研究 がなされている。例えば，後藤ら泉の研究では，植生指 標を斜面災害の発生素因の一つと考え，これまでの地形 ・地質的な素因に付加し, 数量化手法を適用している。 さらに，杉山ら 2)は，植生情報と地形・地質的な素因に 数量化正類を適用した一連の解析を道路防災の予知シス テム確立のための手法として位置付けている。また，大 林ら ${ }^{3)}$ は, ミニマックス法を主体に, 衛星データから求 めた植生指標情報と地形・地質情報を用いた数量化 II類 による斜面災害の発生の危険性の有無について研究して いる。

しかし, これらの研究では, 対象とする地すべりや崩 壊を，その発生パターンが同一のものと仮定して，発生 危険度評価を試みている。さらには，各発生素因情報を メッシュ単位でとらえている場合が多い。

メッシュ単位で崩壊発生に関与する各発生素因を抽出 していく場合, 災害の発生部々不安定土塊の部分とが, 同じように扱われてしまうおそれがあり，崩壊の発生筒 所に沿って「線状」に素因を抽出し，分析することがで きる手法の確立が必要である。

\section{3. 研 究の内 容}

\section{1 崩壊発生素因情報の抽出と斜面崩壊との関連}

一般的に斜面災害の発生箇所に打ける素因を分析して いく際，「どこで発生したか」という側面から発生素因 を分析していく場合と，「どんな規模で発生したか」と いう側面からの分析とに大別されよう。「どこで発生し たか」という側面功とらえる場合は, 斜面災害の発生 区や堆積区などを一つの点として代表させて扱うもの で，平均的な面から斜面災害箇所の素因を分析している にすぎない。をた，「どんな規模で発生したか」という 側面からとらえる場合には，斜面災害の発生区を一つの 点として代表させるのではなく, 面として扱っていく必 要がある。さらに，発生素因の分析をより深めていく場 合「どんなところで発生したか」という側面から発生 素因を分析していく必要がある。その場合，例えば崩壊
の発生箇所や地すべりの滑落崖などを線として分析する ことが重要であり，解析方法としては，これらを表現で きる大きさの画素を単位として画像を重ね合わせる手法 が有効である。

「どんなところで斜面災害が発生したか」という側面 加発生素因を線状に分析していくには，災害発生前後 に撮影された空中写真画像と，関連する素因情報（土地 条件的な素因情報を画像化したもの）との画像同士の重 ね合わせ処理4を適用する。そのためには, 空中写真画 像の厳密な幾何学的な歪及補正 5 を行う。これにより, 斜面災害発生前後の空中写真画像と, 関連する各種の素 因情報（とくに土地条件に基づく素因）を画像として重 ね合わせ，どんな土地条件のところで斜面災害が発生し たか，さらには同じような土地条件の組み合わせが考元 られる所が他にあるか（あるとすれば，土地条件から見 て今後，災害発生箇所として懸念されよう）を知ること ができる。

\section{2 崩壊発生素因情報のグループ化と崩壊発生パ夕 ーンの区分}

ここでは，3.1節での適用手法によって抽出された崩 壞地を線状に，各素因情報を用いて類似の素因グループ 単位で集合化を図る。それによって関連の深い素因同士 の関係を分析していくことができる。そのために，本研 究では, 数量化而類 6 , , クラスタリングの 2 手法を用い る。

数量化正類は質的データに対する正準相関分析であ り，外的基準を必要とせず，多数の要因を少数の総合項 目に縮約する場合に用いられる。

数量化四類の計算では，サンプル数が極めて少ないカ テゴリーを統合し，繰り返し計算を行う。この計算結果 が原データの情報を十分縮約しているか検討した後, 崩 壞パターンの分類に用いる軸を設定する。検討は，(1)軸 毎の意味付け，(2)使用軸の設定，について行う。

数量化亚類の計算結果では, 計算に用いたアイテム, カテゴリーと同数の固有值が抽出される。それぞれの固 有値（值の大きいものから順に第 1 ，第 $2 \cdots \cdots$ とする） に対応して, アイテム, カテゴリ一毎に得点（カテゴリ 一・スコア）が与えられる。このうち，固有値の大きな 場合（すなわち，カテゴリー・スコアとサンプル・スコ アの相関が高い場合), 同時に出現することの多いカテ ゴリーには值の近いスコアが与えられるため, その得点 をもとに分類を行うことができる。

数量化亚類により算出された素因カテゴリーのスコア に対し，クラスタリング手法を適用し，素因カテゴリー のグルーブ化を行う。これにより，既往崩壊箇所をクラ 
スタリング結果に従って類型区分する。類型区分の方法 は, 崩壞発生パターン毎に関与する素因カテゴリーを重 ね合わせた画像を作成し, 各崩壊地がどの類型と重合す るか検討し，類型区分する。

\section{3 崩壊発生パターン別の類似箇所の推定}

ここでは，3.2節でなされた崩壊発生形態別の素因情 報の重なり具合を基準として, 発生形態別に卓越する素 因情報を重ね合わせ，崩壊の発生形態を区分する。崩壊 類型別の画像を作成するに際しては，類型毎に崩壊発生 に重要な影響を及ぼすと考えられるカテゴリーのみを抽 出して重ね合わせる。崩壊発生に関与して, かつ重要な カテゴリーの抽出にあたっては, 相対頻度を用いた（筆 者らは，これを相対頻度法と仮称する7)。以下，本文中 では相対頻度法として用いる)。相対頻度法は, 図-1 に示すように, 各カテゴリーの崩壊地における出現率と 対象斜面全域での出現率の比で表すものである。すなわ ち, 既往崩壊箇所の画像と各発生素因画像を画像解析シ ステム上で重ね合わせることにより，崩壊地に対応する 画素を発生素因情報加抽出する。抽出した画素に対し て, カテゴリー毎に崩壊地の全画素数で除し, 崩壊箇所 に占めるカテゴリー別の面積率を求め, その值をカテゴ リ一の寄与度と考える。さらに, 求めた寄与度を対象斜 面全体に打的カテゴリ一別面積比で除して求めたもの が相対頻度である。相対頻度が 1 以上であれば，崩壊 発生に何らかの関係がある発生素因カテゴリーであると 考えられる。

\section{4. 解析対象地域および使用データ}

本研究では, 1982 年 7 月 23 日夕方から 24 日未明にか けて長崎地区を襲った局地的な集中豪雨に伴う表層崩壊 地を対象とし, 解析対象地域は長崎市内と大村空港を結 ぶ長崎バイパス沿いの山岳地とした（図 -2 , 写真 -1 )。

この豪雨災害の経過は次のようであった8)。九州南岸 にあった梅雨前線は23日朝, 北上して九州北部に停滞 し，対馬海流方面に現れた低気圧に向かって湿った空気 が流れ込み, 前線を刺激した。このため, 高さ $10 \mathrm{~km}$ を越す厚い雨雲が長崎市から雲仙にかけての一帯を覆っ た。この雨雲は, 長浦岳で23日午前 6 時から 7 時まで の 1 時間に $115 \mathrm{~mm}$ という記録的な大雨を降らせた。 この結果, 長崎市とその周辺地域では, 山地における土 石流や崩壊などの土砂災害, 河川の下流部における浸水 や土砂の堆積などを引き起こした。

この豪雨による土石流・山崩れの発生地域を地質的に 分類すると, (1)川平閃緑岩地域, (2)長崎火山岩地域, (3) 井桶ノ尾火山岩地域, (4)古第三紀層地域, (5)西彼杵変成

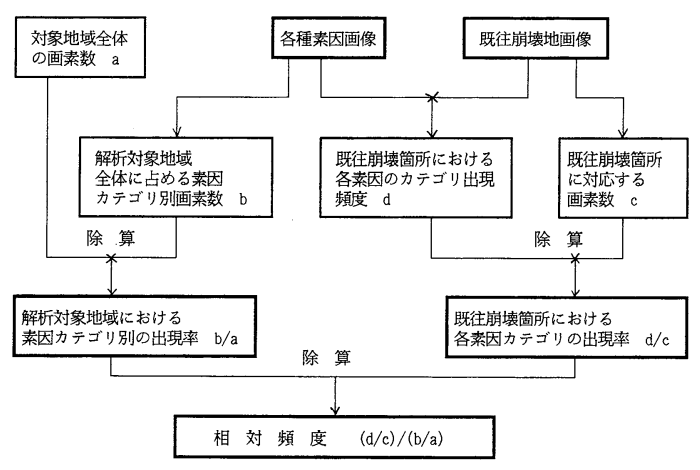

図 - 1 相対頻度の計算方法

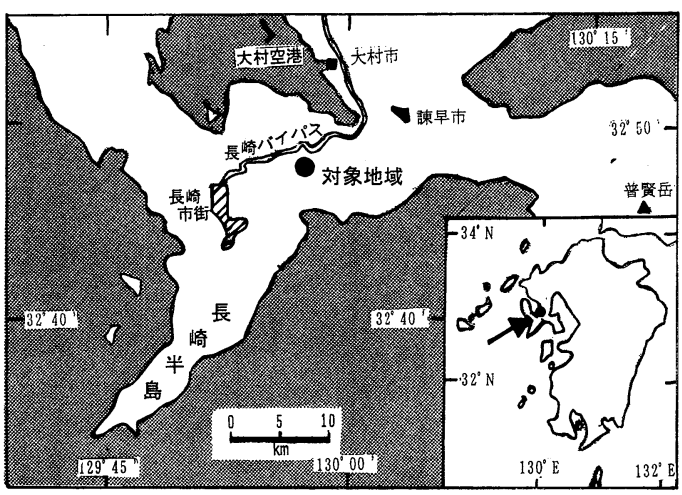

図-2 解析対象地域位置図

岩地域に区分される。このうち, 解析対象とした前岳地 区は長崎火山岩地域に相当している。

長崎火山岩地域は, 輝石安山岩と凝灭角唩岩とが重な り合う構造を持つ。この岩石の分布地域は, 傾斜の小さ い谷地形に降雨が集中し, 表層部を被覆する崩積土を洗 掘しつつ崩壊している場合が多い。

解析に使用したデータは次のとおりである。

(1) 災害発生前撮影のカラー空中写真（スキャナー入力 後, 画像データとして使用)

（2）災害発生後撮影のカラー空中写真（スキャナー入力 後, 画像データとして使用)

（3） $1: 2,500$ 都市計画図の等高線を入力して作成した 数值地形モデル (Digital Terrain Model: DTM と略 される。以下，DTM を用いる。さらにDTM より傾 斜, 斜面縦断形, 斜面横断形データを作成)

\section{5. 崩壊発生素因情報と崩壊地との関係}

\section{1 使用した崩壊発生素因情報}

本研究では，長崎バイパス沿いの前岳地区（約 1.5 
表 - 1 解析に使用した発生素因情報

\begin{tabular}{|c|c|c|c|}
\hline アイテム & \multicolumn{3}{|c|}{ カテゴリー } \\
\hline 遷急線か & 1 & \multicolumn{2}{|l|}{$0-10 \mathrm{~m}$} \\
\hline \multirow[t]{3}{*}{ らの距離 } & 2 & \multicolumn{2}{|l|}{$11-20 \mathrm{~m}$} \\
\hline & 3 & \multicolumn{2}{|l|}{$21-30 \mathrm{~m}$} \\
\hline & 4 & \multicolumn{2}{|l|}{$31 \mathrm{~m}$ 以上 } \\
\hline ガリ・水 & 1 & \multicolumn{2}{|l|}{$0-10 \mathrm{~m}$} \\
\hline 系からの & 2 & \multicolumn{2}{|l|}{$11-20 \mathrm{~m}$} \\
\hline 距離 & 3 & \multicolumn{2}{|l|}{$21-30 \mathrm{~m}$} \\
\hline & 4 & \multicolumn{2}{|l|}{$31-40 m$} \\
\hline & 5 & \multicolumn{2}{|l|}{$41 \mathrm{~m}$ 以上 } \\
\hline 集水地形 & 1 & \multirow{2}{*}{\multicolumn{2}{|c|}{$\begin{array}{l}\text { 集水地形 } \\
\text { 售水地形以外 }\end{array}$}} \\
\hline の有無 & 2 & & \\
\hline \multirow[t]{4}{*}{ 傾 斜 } & 1 & \multicolumn{2}{|c|}{$0-10^{\circ}$} \\
\hline & 2 & \multicolumn{2}{|l|}{$11-20^{\circ}$} \\
\hline & 3 & \multicolumn{2}{|l|}{$21-30^{\circ}$} \\
\hline & 4 & \multicolumn{2}{|l|}{$31^{\circ}$ 以上 } \\
\hline \multirow{8}{*}{ 斜面形状 } & \multirow{3}{*}{$\begin{array}{l}1 \\
2\end{array}$} & \multirow{2}{*}{\multicolumn{2}{|c|}{$\begin{array}{cc}\text { 横 断 縦 断 } \\
\text { 凹 } & \text { 凹 }\end{array}$}} \\
\hline & & & \\
\hline & & 凹 & 平 坦 \\
\hline & 3 & 平 坦 & 凹 \\
\hline & 4 & \multirow{2}{*}{$\begin{array}{l}\text { 平 坦 } \\
\text { 平 坦 }\end{array}$} & 平 坦 \\
\hline & \multirow{2}{*}{6} & & 凸 \\
\hline & & \multirow{2}{*}{ 凸 } & 平 坦 \\
\hline & 7 & & 凸 \\
\hline \multirow[t]{6}{*}{ 植被分類 } & 1 & \multicolumn{2}{|l|}{ 裸地 } \\
\hline & 2 & \multicolumn{2}{|l|}{ 草地 } \\
\hline & 3 & 広 葉 樹 & （密） \\
\hline & 4 & 広 葉 樹 & （粗） \\
\hline & 5 & 針 葉 樹 & （密） \\
\hline & 6 & 針葉 樹 & （粗） \\
\hline 植被境界 & 1 & $0-10 \mathrm{~m}$ & \\
\hline からの & 2 & $11-20 \mathrm{~m}$ & \\
\hline 距離 & 3 & $21-30 \mathrm{~m}$ & \\
\hline & 4 & $31 \mathrm{~m}$ 以上 & \\
\hline
\end{tabular}

$\mathrm{km} \times 2.2 \mathrm{~km})$ を解析対象地域とし，地形・植生等の素 因情報を空中写真判読，画像解析，DTM を用いて，画 像データ化した。その際, 画像データの最小単位である 1 画素の大きさは，実長で $2 \mathrm{~m}$ 四方とした。すべての素 因データに対して，統一の座標系を設定し，正射変換， アフィン変換により位置を合わせた。また，素因情報は 数量化計算に用いるため, 表 -1 に示すカテゴリーデー タとした。写真一2,3には，代表的な素因情報を示す。

\section{(1) ガリからの距離}

ガリは, カラー空中写真の判読により抽出した。ガリ の影響は，その直上の久ではなく，周囲に対しても考え られることから，ここでは画像の全画素について最近隣 のガリからの距離を計算し，素因画像とした。

(2) 集水地形

集水地形は，地形図の等高線の並びから判然とするも のと，現地調查による補足を加えて明らかにしたものと を用いた。

(3) 遷急線加らの距離

遷急線は地形図の判読から抽出し，ガリの場合と同様 に遷急線の位置からの距離について計算した。

(4) 傾斜

地形図上から $2 \mathrm{~m}$ 間隔で等高線をすべて入力し，デ イジタル標高データを作成した。これを用いて計算処理

し, 各画素の最大傾斜方向の傾斜角を求めた。

(5) 斜面縦断形

斜面縦断形画像の作成は，傾斜と同様に計算処理によ

り，斜面形状を凹形，平坦形，凸形に区分した。

(6) 斜面横断形

斜面縱断形と同様の手法で，最大傾斜方向に直交する 方向の斜面形状を求めた。斜面形状は凹形, 平坦形, 凸 形に区分した。

(7) 植被

難波9にによれば，無林地よりも有林地の方が崩壊が少 なく，また，有林地のなかでは林龄が高いほど崩壊が少 ないことを指摘している。

そこで，有林地と裸地や草地等の無林地をカラ一空中 写真画像を用いて，自動判別により分類した。なお，力 ラー空中写真画像の自動判別に当っては, カラー空中写 真を，入力用のスキャナーを通して青色・緑色・赤色デ 一タに色分解したうえで, 画素単位で植被状況を分類し た。

８）植生境界からの距離

植生境界とは，植生タイプの境界線や森林内での樹高 階の境界線, 植生域と人工構造物の境界線等がこれに当 る。植生境界付近では，表流水の流れや，樹木の根茎に よる表土の締め固め力が急激に変化することから崩壞の 発生しやすい状況にある。そこで，植被分類画像から異 なるカテゴリーが接する地点を抽出し，その地点からの 距離を全画素について計算したものを素因情報の一つと して用いた。

以上の各素因情報に加え，災害発生直後に撮影した力 ラ一空中写真を正射変換し，崩壊発生箇所の情報も整備 した。 


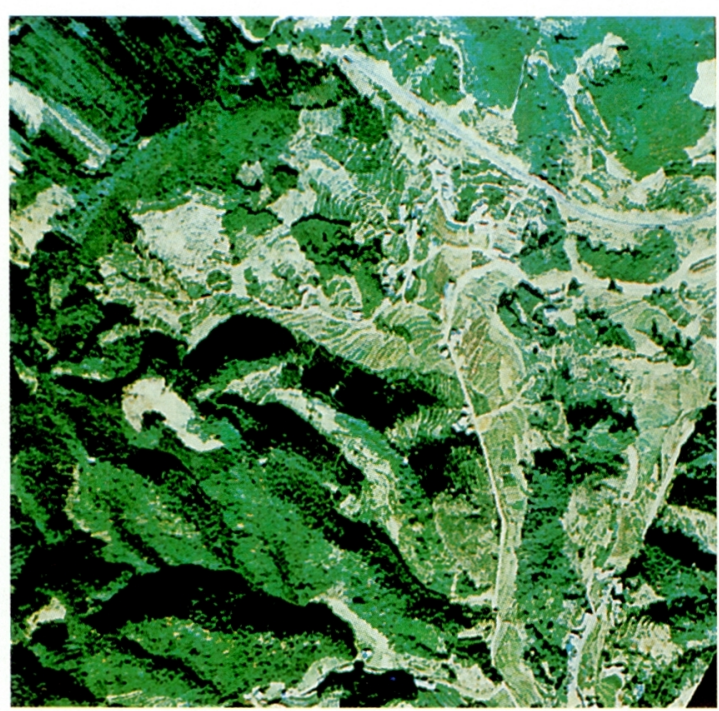

写真 -1 空中写真画像

表-2 アイテム別のレンジ

\begin{tabular}{|c|c|c|c|c|c|c|}
\hline & & & & ע & & \\
\hline Na & T 1 T $厶$ & 第 1 軸 & 第 2 軸 & 第 3 軸 & 第 4 軸 & 第 5 軸 \\
\hline 1 & 遥急線からの距離 & 6.49185 & 9.15052 & 8.64468 & 5.13092 & 9.84002 \\
\hline 2 & カリ・水系の距敞 & 5.86641 & 5.94777 & 8.42902 & 10.6299 & 7.35063 \\
\hline 3 & 集水地形の有無 & 6.27048 & 2.35336 & 3.29625 & 1.54546 & 1.95129 \\
\hline 4 & 㑯 科 & 5.26209 & 9.85391 & 7.86692 & 5.52406 & 8.40901 \\
\hline 5 & 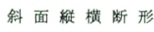 & 5.99859 & 7.26313 & 7. 25530 & 14.6213 & 8.97405 \\
\hline 6 & 植 被 分 類 & 4.77453 & 3.40874 & 6.76989 & 5.67737 & 6.51256 \\
\hline 7 & 植被境界の距離 & 3.10419 & 5.28204 & 8.22600 & 8.13476 & 14.9350 \\
\hline
\end{tabular}

\section{2 崩壊発生素因情報と崩壊箇所との関係}

ここでは, 崩壊発生パターンを客観的に類型区分する ことを目的として, 発生素因情報の集計結果に対し，数 量化正類を適用した。数量化の適用に先立って，7種の 発生素因画像に対して崩壊発生箇所画像を画素単位に重 ね合わせ，124箇所の崩壊地における発生箇所に該当す る1306画素（124箇所の崩壊の発生箇所を線状に画像化 した総画素数）のカテゴリー頻度を集計し, 数量化計算 を用いた。数量化正類の計算では, サンプル数が極めて 少ないカテコ゚リーを統合し，繰り返し計算を行った。

次に, 数量化而類の計算結果が原データの情報を十分 縮約しているかを検討した後, 崩壊発生パターンの分類 に用いる軸を設定した。

（1）軸毎の意味付けの検討

解析対象地域の崩壊発生素因情報に対して数量化III類

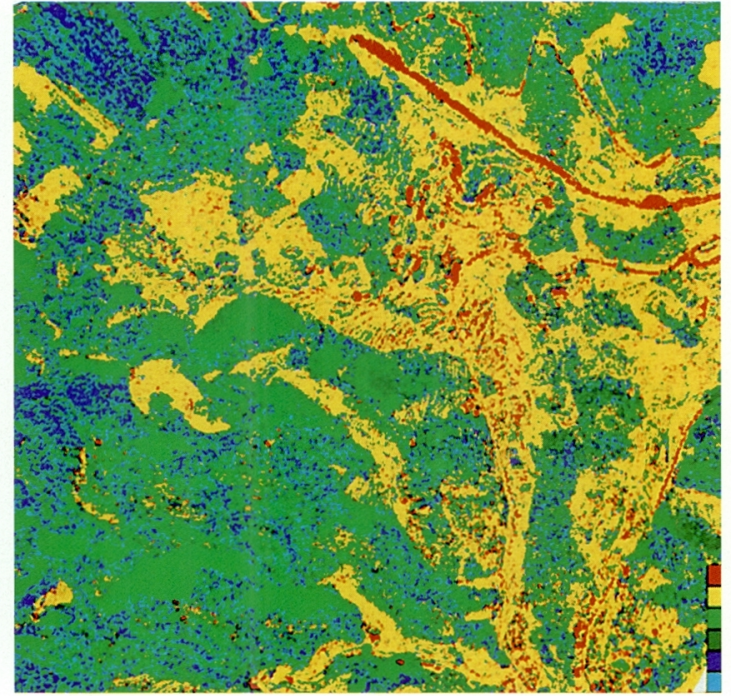

写真 -2 植被分類画像

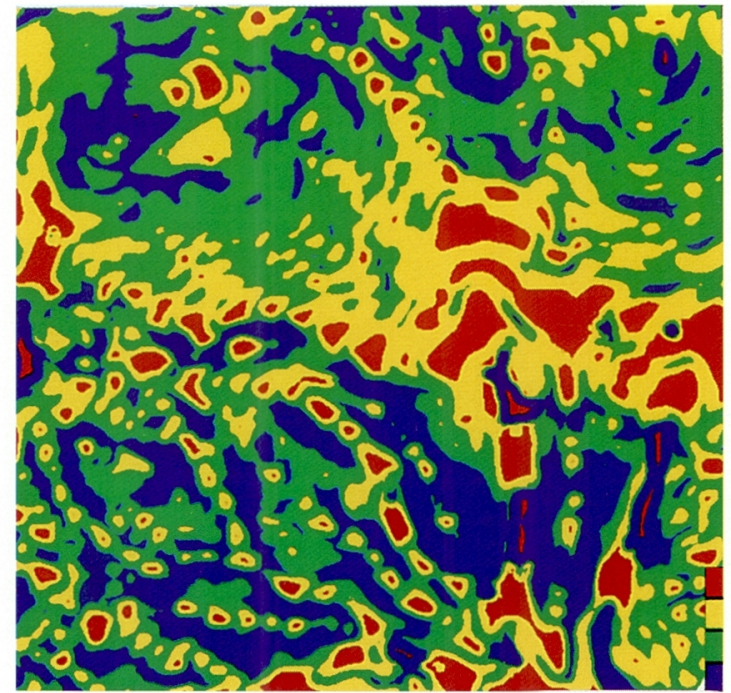

写真 -3 傾斜区分画像

を適用した結果, 表 -2 に示すカテゴリー・スコアのレ ンジを得た。レンジは，アイテム別のカテゴリー・スコ アの最大, 最小值の差であり, レンジが大きいアイテム ほど，その軸における群別分類に重要な因子と考えられ る。

次に，表- 2 に基づき，軸毎の意味付けについて検討 した。

第 1 軸は, 遷急線からの距離，集水地形の有無のレ 


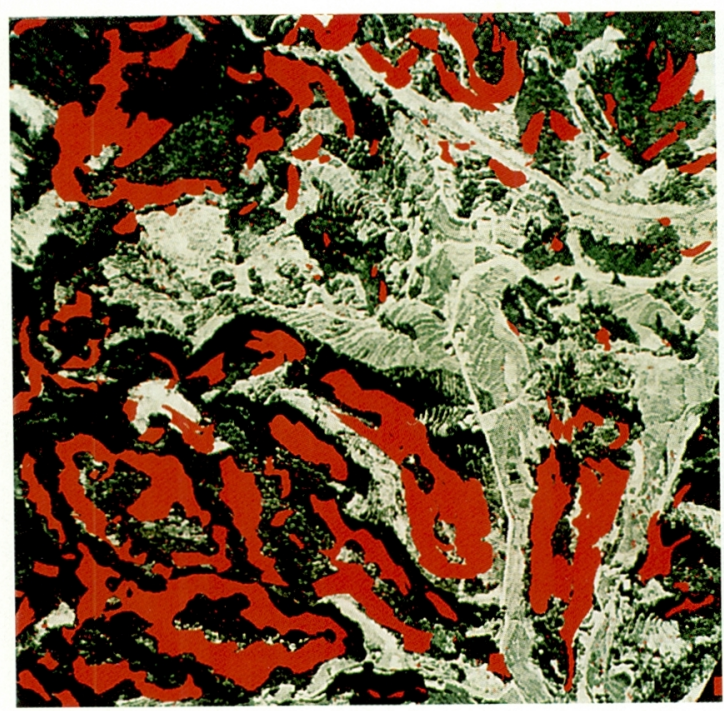

写真 -4 崩壊発生の類似箇所 (A タイプ)

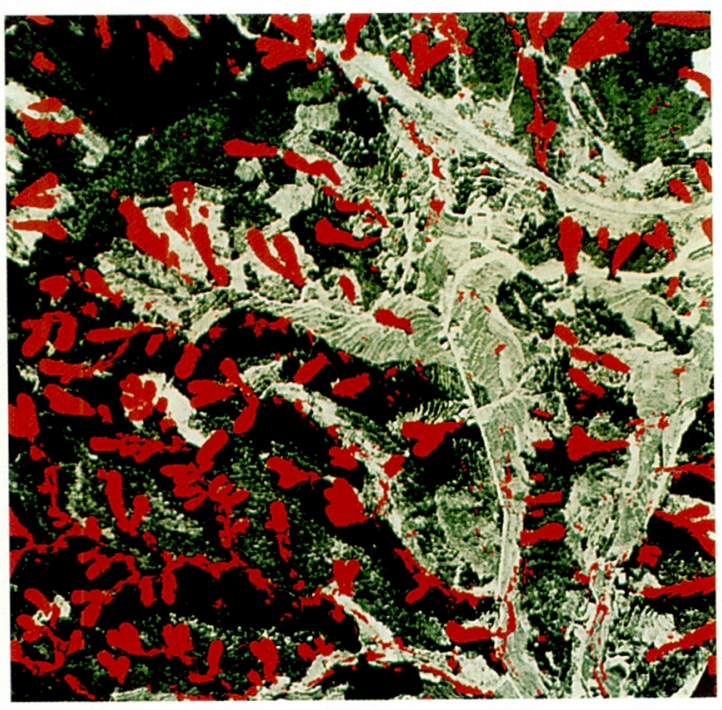

写真 -6 崩壊発生の類似箇所 (Eタイプ)

ソジが比較的大きいものの，概ね全アイテムに均等なも のとなっている（すなわち，後述の第 2 軸以降に比べ, アイテム毎のレンジに大きな差が見られない)。

第 2 軸は, 傾斜, 遷急線からの距離のレンジが大き く，主として傾斜の違いた関した情報を縮約していると 考えられた。

第 3 軸は, 遷急線からの距離, ガリ・水系からの距 離と植被境界からの距離のレンジが概ね同程度であり，

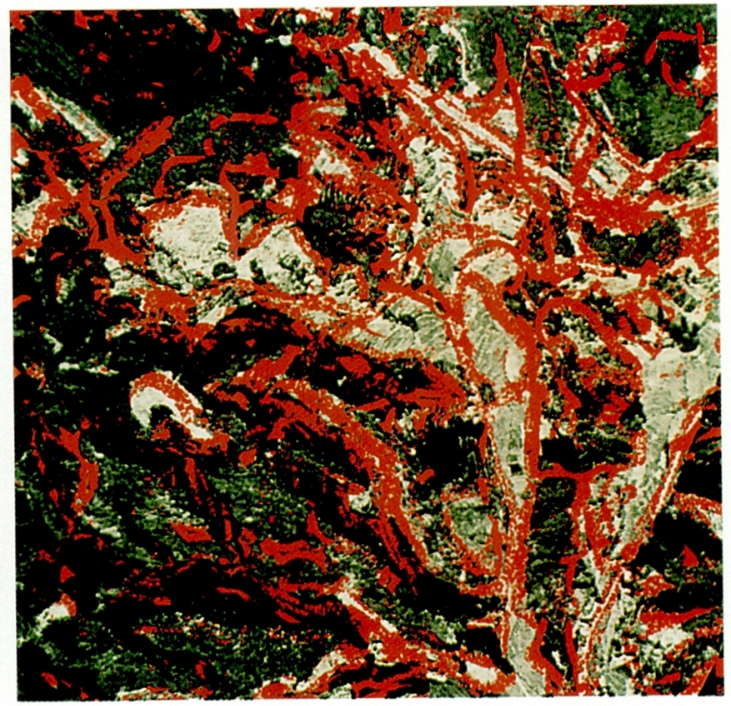

写真 -5 崩壊発生の類似箇所（Bタイプ）

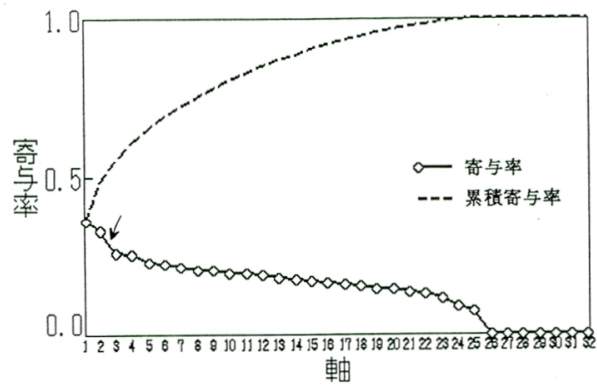

図 - 3 各軸の寄与率および累積寄与率

第 1 軸，第 2 軸と異なった情報を縮約しているのがわ かった。

第 4 軸以降のレンジは第 1 第 3 軸のいずれかと類似 した傾向を示すと考劣られた。

(2) 使用軸の検討

数量化且類により得られた 32 軸のカテゴリー・スコ アの中から，クラスタリングによるグループ化に用いる 軸とそのカテゴリー・スコアを選別した。

図-3 に各軸の寄与率抢よび累積寄与率を示す。ま た，表-3に寄与率の計算に用いた各軸の固有值を示 す。図-3では, 第 3 軸以降の寄与率が漸減傾向を示し ている。寄与率の大きさが, 比較的明瞭に変化するのは 第 2 軸と第 3 軸の間と, 第 25 軸と第 26 軸の間において である（第29軸以降は計算誤差である。これは，使用 した計算プログラムが，限りなく 0 に近い固有值を正 確に表示しないためである)。最初に現れる寄与率の大 


\section{表 -3 数量化正類による固有値}

\begin{tabular}{|c|c|c|c|}
\hline No. & 固 有 值 & No. & 固 有 値 \\
\hline 1 & 0.271512 & 17 & 0.122258 \\
2 & 0.246789 & 18 & 0.116513 \\
3 & 0.198018 & 19 & 0.111427 \\
4 & 0.191699 & 20 & 0.109438 \\
5 & 0.175493 & 21 & 0.102037 \\
6 & 0.169743 & 22 & 0.099009 \\
7 & 0.160995 & 23 & 0.089530 \\
8 & 0.155335 & 24 & 0.071367 \\
9 & 0.152984 & 25 & 0.058826 \\
10 & 0.149547 & 26 & 0.000021 \\
11 & 0.147415 & 27 & 0.000003 \\
12 & 0.143938 & 28 & 0.000001 \\
13 & 0.136173 & 29 & 計算誤差* \\
14 & 0.134094 & 30 & " \\
15 & 0.130442 & 31 & \multicolumn{2}{|l}{} \\
16 & 0.126874 & 32 & " \\
\hline
\end{tabular}

*計算結果の出力に際しては, 8 桁表示のため不 確定な数值が表示された。

筆者らはこれを「計算誤差」と表記した。

きな変化は主要な情報の多くが，その軸までに抽出され たことを示すものと言える。しかし，累積寄与率に着目 すると，第 1 ，第 2 軸まででは 0.5 と低く，第 1,2 軸を もって原データを代表していると見るのは不十分である と考えられた（菅 ${ }^{10}$ は，累積寄与率 0.6 程度を軸数設定 の目安としている)。これと，(1)の各軸の意味付けにお いて第 1 第 3 軸が異なる主要な情報を縮約していたこ とを考え合わせ，第 3 軸（累積寄与率0.6）を解析に加 えることが妥当と判断した。

以上のことから, 解析対象地域の解析には第 1 第 3 軸までのカテゴリー・スコアを用いることとした。

\section{6. 崩壊発生素因情報のグループ化と崩壊発生パ ターンの区分}

数量化正類による第 1～第 3 軸のカテゴリー・スコア の值を階層的クラスタリング手法により分類した。階層 的クラスタリング手法として，ウォード法（クラスター 統合後の情報損失量を最小とするクラスターの統合を行 う方法）を適用した。

階層的なクラスタリング手法では，全データが 1 つ のクラスターに統合されるまで計算を続けるため，最終 クラスターの数を任意に指定して希望のクラスター数に する必要がある。図-4でクラスター毎のまとまりが明

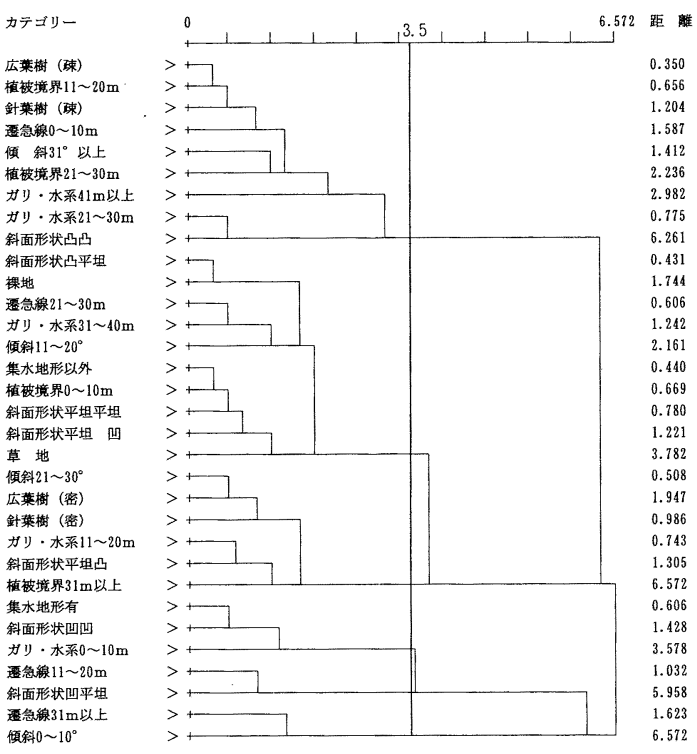

図-4 クラスター統合のためのデンドログラム

瞭となる距離（今回の場合は3.5付近）に基づき，6 種 類のクラスターを採用した。

各クラスターに含まれる素因と，それから類推される 崩壊発生パターンを表一 4 に示す。

（1）タイプ A は, 遷急線の近傍や急傾斜地で発生して いた崩壊のパターンであり，いわゆる傾斜に起因した崩 壊である。

（2）タイプ Bは，遷急線近傍や急傾斜地との関連は薄 いが，植被の貧弱なところで発生していた崩壊である。

(3) タイプ C は, タイプ B と類似するパターンであり, 主として森林内で植被の少ない筒所（例えげ伐採跡地な ど）で発生していた崩壊である。

（4）タイプDは, タイプ A に近いパターンであり, 比 較的傾斜の急な箇所で発生していた崩壊である。

(5) タイプ $\mathrm{E} は$ は, 集水しやすい地形条件（斜面の縌横 断形がともに凹形, 集水地形が存在, ガリ・水系から近 距離内に存在）の所で発生していた崩壊である。

(6) タイプ $\mathrm{F}$ は, 耕作地内（段々畑など）や林道内の 法肩で発生していた崩壊である。

各タイプの素因カテゴリーをもつ崩壊筒所数を集計し たところ，タイプ $\mathrm{A} \sim \mathrm{F}$ に属すると考えられるものが， それぞれ，20箇所 $(16.1 \%) ， 31$ 箇所 $(25.0 \%) ， 17$ 箇所 $(13.7 \%) ， 18$ 箇所 $(14.6 \%) ， 4$ 箇所 $(3.2 \%) ， 3$ 箇所 (2.4\%) であった。この他に，31箇所 $(25.0 \%)$ が，複 数のタイプの素因を合わせ持っていた（この集計は，実 長 $2 \mathrm{~m}$ 四方の画素を単位とした素因情報に基づくもの 
表 -4 崩壊の発生パターン

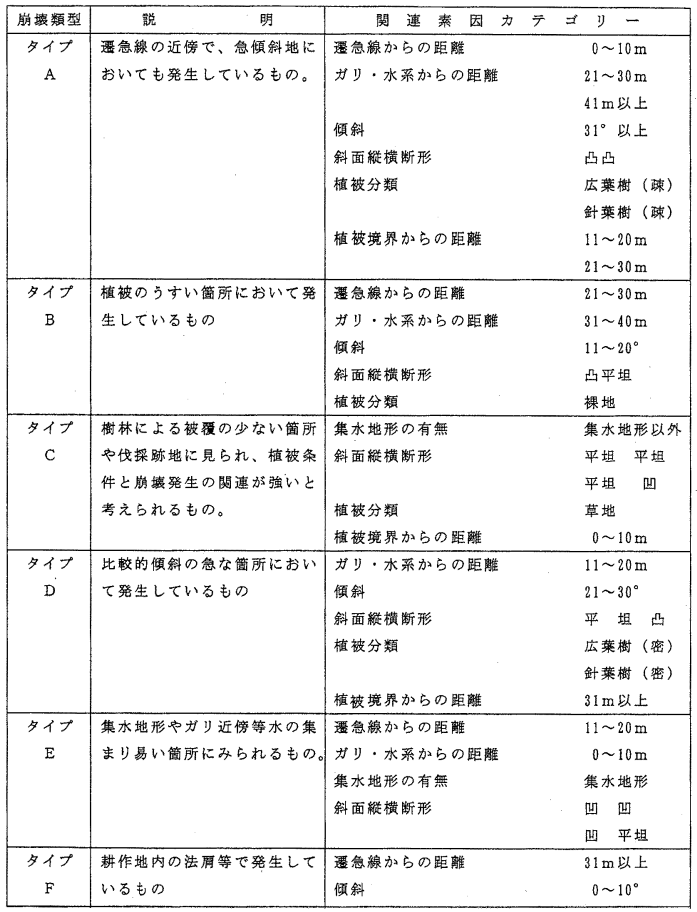

であり，4章で述べた対象地域に抢ける崩壊分布の地形 的特性に比べ微視的なものである)。

\section{7. 崩壊発生パターン別に見た類似箇所の抽出}

ここでは，崩壊発生パターン毎に崩壊発生に重要な影 響を与えたと考えられるカテゴリーのみを抽出して重ね 合わせ, 崩壊発生パターン別の類似箇所の抽出を試み た。崩壊発生に重要な影響を与えたと考えられるカテゴ リーの抽出には，相対頻度法を用いた。

この方法では, あるカテゴリーが斜面全体での出現率 に比べ，崩壊地に㧍いて特に多く分布するほど大きな寄 与度として算定される。

以上の 2 手法により計算された各カテゴリーの頻度, 相対頻度を表 -5 に示す。同表の相対頻度が 1.0 より大 きなカテゴリーは, 崩壊発生に関与しているものと考え られる。逆に相対頻度の値が1.0以下の場合は, 崩壊発 生とカテゴリーの関連性がない，もしくは非発生に関与 していると言える。

次に, 崩壊発生パターン別の関連素因カテゴリーの中 から, 相対頻度の高いもののみを画素単位で重ね合わせ た。その代表的な解析結果を写真 $-4 \sim 6$ (p. 19, 背景 は崩壊発生前の空中写真）に示す。
表 -5 アイテム・カテゴリ一別の頻度 $(\mathrm{A}) \cdot$ 相対頻度 $(\mathrm{A} / \mathrm{B})$

\begin{tabular}{|c|c|c|c|c|}
\hline $31 \% 4$ & カテコリー & 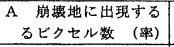 & \begin{tabular}{|c|}
$\mathrm{B} \quad$ 対象地城全体での \\
出現ピグル数(率)
\end{tabular} & $\begin{array}{c}\text { 相 対 戝 度 } \\
(\mathrm{A} / \mathrm{B})\end{array}$ \\
\hline \multirow{4}{*}{$\begin{array}{l}\text { 避 } \\
\text { 急 } \\
\text { 線 } \\
\text { 足 } \\
5 \\
0 \\
\text { 距 } \\
\text { 雄 }\end{array}$} & $0 \sim 10 \mathrm{~m}$ & $\begin{array}{c}793 \\
(60.8 \%) \\
\end{array}$ & $\begin{array}{c}237033 \\
(50.1 \%)\end{array}$ & 1.21 \\
\hline & $11 \sim 20 \mathrm{~m}$ & $\begin{array}{c}280 \\
(21.4 \%)\end{array}$ & $\begin{array}{l}102746 \\
(21.7 \%)\end{array}$ & 0.99 \\
\hline & $21 \sim 30 \mathrm{~m}$ & $\begin{array}{c}149 \\
(11.4 \%) \\
\end{array}$ & $\begin{array}{l}54343 \\
(11.5 \%) \\
\end{array}$ & 0.99 \\
\hline & $31 \mathrm{~m}$ 以上 & $\begin{array}{c}84 \\
(6.4 \%) \\
\end{array}$ & $\begin{array}{l}78860 \\
(16.7 \%)\end{array}$ & 0.38 \\
\hline \multirow{5}{*}{ 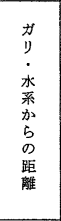 } & $0 \sim 10 \mathrm{~m}$ & $\begin{array}{c}499 \\
(38.2 \%) \\
\end{array}$ & $\begin{array}{c}158774 \\
(33.6 \%) \\
\end{array}$ & 1.14 \\
\hline & $11 \sim 20 \mathrm{~m}$ & $\begin{array}{c}364 \\
(27.9 \%)\end{array}$ & $\begin{array}{c}116557 \\
(24.6 \%)\end{array}$ & 1.13 \\
\hline & $21 \sim 30 \mathrm{~m}$ & $\begin{array}{c}187 \\
(14.3 \%)\end{array}$ & $\begin{array}{l}85937 \\
(18.2 \%) \\
\end{array}$ & 0.79 \\
\hline & $31 \sim 40 \mathrm{~m}$ & $\begin{array}{c}159 \\
(12.2 \%)\end{array}$ & $\begin{array}{l}48142 \\
(10.2 \%)\end{array}$ & 1.20 \\
\hline & $41 \mathrm{~m}$ 以上 & $\begin{array}{c}97 \\
(7.4 \%) \\
\end{array}$ & $\begin{array}{l}63572 \\
(13.4 \%) \\
\end{array}$ & 0.55 \\
\hline \multirow{2}{*}{$\begin{array}{ll}\text { 集 } & \text { の } \\
\text { 水 } & \text { 有 } \\
\text { 地 } & \text { 無 } \\
\text { 形 } & \end{array}$} & 集水地形 & $\begin{array}{c}259 \\
(19.8 \%) \\
\end{array}$ & $\begin{array}{l}67215 \\
(14.2 \%) \\
\end{array}$ & 1.39 \\
\hline & 集水地形以外 & $\begin{array}{c}1047 \\
(80.2 \%) \\
\end{array}$ & $\begin{array}{c}405767 \\
(85.8 \%) \\
\end{array}$ & 0.93 \\
\hline \multirow{4}{*}{ 傾 } & $0 \sim 10^{\circ}$ & $\begin{array}{c}85 \\
(6.5 \%) \\
\end{array}$ & $\begin{array}{l}48858 \\
(10.3 \%) \\
\end{array}$ & 0.63 \\
\hline & $11 \sim 20^{\circ}$ & $\begin{array}{c}260 \\
(19.9 \%) \\
\end{array}$ & $\begin{array}{c}121914 \\
(25.8 \%) \\
\end{array}$ & 0.77 \\
\hline & $21 \sim 30^{\circ}$ & $\begin{array}{c}639 \\
(48.9 \%) \\
\end{array}$ & $\begin{array}{c}198878 \\
(42.1 \%)\end{array}$ & 1.16 \\
\hline & $31^{\circ}$ 以上 & $\begin{array}{c}322 \\
(24.7 \%) \\
\end{array}$ & $\begin{array}{c}103332 \\
(21.8 \%) \\
\end{array}$ & 1.13 \\
\hline \multirow{7}{*}{$\begin{array}{l}\text { 斜 } \\
\text { 面 } \\
\text { 䋖 } \\
\text { 横 } \\
\text { 断 } \\
\text { 形 }\end{array}$} & 横凹 綎 凹 & $\begin{array}{c}159 \\
(12.2 \%) \\
\end{array}$ & $\begin{array}{l}48443 \\
(10.3 \%)\end{array}$ & 1.18 \\
\hline & 凹 平坥 & $\begin{array}{c}138 \\
(10.6 \%) \\
\end{array}$ & $\begin{array}{l}39677 \\
(8.5 \%)\end{array}$ & 1.25 \\
\hline & 平坦 凹 & $\begin{array}{c}160 \\
(12.2 \%) \\
\end{array}$ & $\begin{array}{l}40863 \\
(8.7 \%) \\
\end{array}$ & 1.40 \\
\hline & 平坦 平坦 & $\begin{array}{c}572 \\
(43.88)\end{array}$ & $\begin{array}{r}226500 \\
(48.2 \%)\end{array}$ & 0.91 \\
\hline & 平坦 凸 & $\begin{array}{c}76 \\
(5.8 \%) \\
\end{array}$ & $\begin{array}{l}31733 \\
(6.8 \%) \\
\end{array}$ & 0.85 \\
\hline & 凸平坥 & $\begin{array}{c}116 \\
(8.9 \%) \\
\end{array}$ & $\begin{array}{l}40655 \\
(8.7 \%) \\
\end{array}$ & 1.02 \\
\hline & 凸 & $\begin{array}{c}85 \\
(6.5 \%) \\
\end{array}$ & $\begin{array}{l}41053 \\
(8.8 \%) \\
\end{array}$ & 0.74 \\
\hline \multirow[b]{2}{*}{ 植 } & 裸地 & $\begin{array}{l}114 \\
(8.7 \%) \\
\end{array}$ & $\begin{array}{l}42582 \\
(9.0 \%) \\
\end{array}$ & 0.97 \\
\hline & 草地 & $\begin{array}{c}347 \\
(26.6 \%) \\
\end{array}$ & $\begin{array}{l}92397 \\
(19.5 \%)\end{array}$ & 1.36 \\
\hline 被 & 広 葉榯（密） & $\begin{array}{c}423 \\
(32.3 \%)\end{array}$ & $\begin{array}{l}154456 \\
(32.7 \%)\end{array}$ & 0.99 \\
\hline 分 & 広 葉 楖 (踈) & $\begin{array}{c}221 \\
(16.9 \%) \\
\end{array}$ & $\begin{array}{l}80030 \\
(16.9 \%)\end{array}$ & 1.00 \\
\hline \multirow[t]{2}{*}{ 類 } & 针 莱楖（密） & $\begin{array}{c}176 \\
(13.6 \%) \\
\end{array}$ & $\begin{array}{l}95576 \\
(20.2 \%) \\
\end{array}$ & 0.67 \\
\hline & 針 葉 樹（踈） & $\begin{array}{c}25 \\
(1.9 \%) \\
\end{array}$ & $\begin{array}{c}7941 \\
(1.7 \%) \\
\end{array}$ & 1.12 \\
\hline \multirow{4}{*}{$\begin{array}{l}\text { 椺 } \\
\text { 生 } \\
\text { 境 } \\
\text { 界 } \\
\text { 力 } \\
5 \text { 距 } \\
\text { の離 }\end{array}$} & $0 \sim 10 \mathrm{~m}$ & $\begin{array}{c}792 \\
(60.6 \%)\end{array}$ & $\begin{array}{r}218259 \\
(46.1 \%)\end{array}$ & 1.31 \\
\hline & $11 \sim 20 \mathrm{~m}$ & $\begin{array}{c}275 \\
(21.0 \%) \\
\end{array}$ & $\begin{array}{c}109574 \\
(23.2 \%)\end{array}$ & 0.91 \\
\hline & $21 \sim 30 \mathrm{~m}$ & $\begin{array}{c}121 \\
(9.3 \%) \\
\end{array}$ & $\begin{array}{l}56216 \\
(11.9 x) \\
\end{array}$ & 0.78 \\
\hline & $31 \mathrm{~m}$ 以上 & $\begin{array}{l}118 \\
(9.1 \%) \\
\end{array}$ & $\begin{array}{l}88933 \\
(18.8 \%) \\
\end{array}$ & 0.48 \\
\hline
\end{tabular}

（1）タイプ Aの類似箇所は, 遷急線の近傍に多く, 傾 斜が急な斜面中央部に多く見られる。このタイプの既往 崩壞地㧍よび類似箇所が比較的多い。このタイプの類似 箇所と現地調査での崩壊懸念箇所との整合性は概ね高か った。

(2) タイプ Bの類似箇所は, 斜面中の植被の薄い箇所 に多く分布していた。現地調査で B タイプの崩壊懸念 箇所の確認を行ったところ, 露岩地等が植林地の中に点 在している箇所や, 伐採跡地内の崩壊地や危険箇所が対 仙てていた。 
（3）タイプCの類似箇所は，道路の路肩や植林地の林 道沿い等の植生境界近傍や伐採跡地等の植生の疎な箇所 に多く見られた。現地調査では，林道の周辺にクラック が生じている箇所等が確認された。

(4) タイプ D の類似箇所は, タイプ A の同様の箇所と 似た分布を示していた。両タイプの違いは，植生の踈密 が異なることである。すなわち，表一 4 に示したよう に, タイプ A では広葉樹・針葉樹とも(疎)のカテゴリ 一から構成されるのに対し, タイプDでは(密)のカテ ゴリーから構成されるためである。

(5) タイプ $\mathrm{E}$ の類似箇所は, 集水地形である凹地や, ガリの付近に点在していた。現地調査においても，斜面 中や表土が流出してできたと考えられる凹地形等を確認 できた。

(6) タイプ Fの崩壊は耕作地の人工的な斜面で発生し ているものである。解析による類似箇所は概して, 実際 よりも広範用に抽出されていた（今後, 人工構造物の位 置を加えて解析を行うことにより, 解析結果の絞り込み が必要となろう)。

\section{8. まとめ}

本研究は, 1982年 7 月に発生した長崎大水害に伴う 表層部での崩壊箇所を対象に, 表層部の崩壞の発生パタ ーン区分を画像解析手法を主体に試みた。それにより, 発生パターン別の崩壊に対する関与度合の高い発生素因 情報を明確にし, 発生パターン別に崩壊を分析する方法 について検討した。

本研究を通じ，次のような知見を得ることができた。 （1）前岳地区の解析では, 長崎大水害時の同一誘因によ って生じた崩壊地（124籄所）について，画像の重ね合 わせ処理と数量化理論を併用した手法を適用した。その 結果, 崩壊の発生パターンを概ね $\mathrm{A} \sim \mathrm{F}$ の 6 パターン に大別することができた。今後, 崩壊発生の予測に当っ ては，それぞれ個別の発生パターン毎に発生の危険度を 検討することが必要とされよう。

（2）画像の重ね合わせ処理と数量化理論を併用した手法 を適用することにより，解析結果をビジュアルなカラー 画像として表示することができ，加えて，抽出された類 似箇所は今後の崩壊発生の逎念箇所と考えることができ る。

以上の上うな研究成果が得られたが, 今後, 本研究を より一層進めていくうえでは, 次のような課題が残され ている。

(1) 数量化類による崩壊発生のパターン化に関する検 証
本研究は, 上記のように崩壊発生のパターン別に分析 することを目的に，そのための解析手法に主眼をおいて 進めた。したがって, マクロな視点からの解析であり, 数量化正類の適用に当っては, 次のような面からの詳細 な検証を今後とも必要とされる。すなわち, 数量化而類 は，外的基準を与えない場合の群別分類を意図した手法 であり, アイテム・カテゴリーとサンプルのグループ化 に用いられる。しかし, 本研究ではアイテム・カテゴリ 一の分類のみを用い, サンプル側の分類結果については 検証を行っていない。そのため，崩壊発生パターンの分 類結果について，今後は十分な検証が必要とされる。ま た，解析結果のうち，固有值が最大である第 1 軸にお

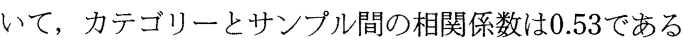
が，筆者らは相関係数 $0.4 \sim 0.7$ は経験的に中程度の相関 があるものとして判断した。今後, より実用性の高い解 析手法を確立していくには，十分な検討が必要とされ る。

（2）崩壊発生素因としての植被情報の重要性とそのため の情報抽出手法

本研究で明らかなように，植被情報の差異（植物の被 覆度の違い，植被の境界線など）により発生した崩壊の 発生パターンが見られた。すなわち，同じ植生域であっ ても, 被覆度の違い（例えば, 森林内の裸地や草地のよ うに周囲の植物被覆との差異）に起因した崩壊が発生し ていた。このようなことから，崩壊発生素因として植被 情報の重要性が考えられる。植被情報は，リモートセン シングが最も得意とする領域である。衛星データやカラ 一空中写真から植被情報を正確に収集するためには，地 形の陰影による影響を除去したり，特殊なフィルターを 用いた画像処理手法の適用による改善が必要とされる。

(3) 画像の重ね合わせ処理と数量化理論の併用による今 後の崩壊発生予測手法

従来から数量化理論は，災害箇所の分析や危険度予測 に用いられてきた手法であり，定量的で，客観的な解析 結果を得ることができるものである。しかしながら，解 析過程の手順の複雑さや繰り返し計算の手間, 解析結果 の視認性などに課題が存在する。そのためには, 数量化 理論の前段で, 画像の重ね合わせ処理を適用し, 解析に 使用するカテゴリーの絞り込みを行う。次に，有力な力 テゴリーを用いて数量化理論を適用し, 崩壊の発生パタ 一ン別に見た今後の発生危険度判定を行うといった段階 的な解析が必要となろう。

さらに，その判定結果を 3 次元画像上に表示したり， 地形図あるいは写真などの画像上に重ね合わせて表示す ること等により，解析結果の視認性が向上し，解析結果 
の妥当性の判断が迅速に進められることとなる。そのた めには, 上記のような併用手法の改善・改良が今後の課 題となる。

\section{参 考 文 献}

1）後藤恵之輔, 棚橋由彦, 後藤正孝, 藤田 徹, 吉住龍也 (1988)：リモートセンシングデータを導入した数量化理 論による地すべりの危険度評価, 第23回土質工学研究発 表会発表講演集; pp. 1819 1820.

2）杉山和一, 後藤恵之輔, 三浦国春, 峰浩二 (1990): 衛星 データを導入した道路防苂の予知システム, 日本写真測量 学会平成 2 年度秋季学術講演会発表論文集, pp. $27 \sim 30$.

3）大林成行, 小島尚人, 笠 博義 (1990): 斜面崩壊予測を 対象とした衛星マルチスペクトルデータの実利用化につい て, 土木学会論文集, 第 $415 / \mathrm{V}-12$, pp. $71 \sim 80$.

4）瀬戸島政博, 白石一夫 (1992)：斜面災害発生地点におけ る素因分析の一手法と応用性について, 応用地質, Vol.
33, No. 2, pp. $22 \sim 30$.

5）瀬戸島政博，大山容一（1991）: 斜面災害の発生地点に打 ける土地条件分析を目的としたカラ一空中写真データの画 像解析手法, 日本リモートセンシング学会誌, Vol. 11, No. 2 , pp. $41 \sim 53$.

6) 駒澤 勉 (1982): 数量化理論とデータ処理, 朝倉書店, 289p.

7）瀬戸島政博, 森 大, 野口達雄, 杉山友康（1991）: 画 像のオーバーレイ手法を用いた斜面災害懸念箇所の抽出に 関する検討, 日本写真測量学会平成 3 年度秋季学術講演会 発表論文集, pp. 115 118.

8）長崎大学学術調査団 (1982) : 昭和57年 7 月長崎豪雨によ る災害の調査報告書.

9）難波宣士（1978）：大政正隆監修/帝国森林会編「森林学」 4.侵食に対する森林の影響, 共立出版, pp. $500 \sim 515$.

10）菅 民郎(1993)：「実践多変量解析」, 社会情報サービス, p. 130 .

（1993年 8 月 2 日受付，1993年12月 1 日受理） 